\title{
Geology of Majuba Hill Pershing County, Nevada
}

GEOLOGICAL SURVEY BULLETIN 1046 -I

This report concerns work done on behalf of the U.S. Atomic Energy Commission

- and is published with the permission of the Commission 


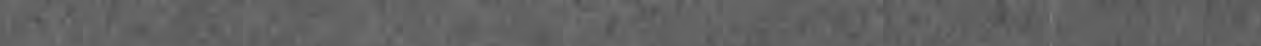

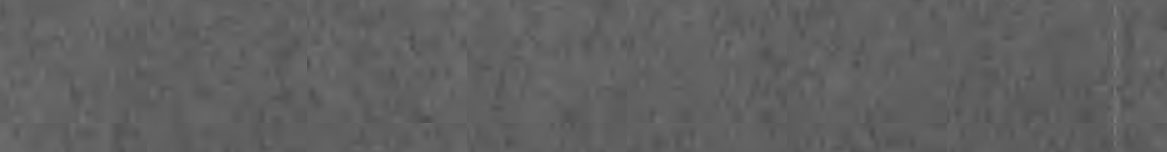

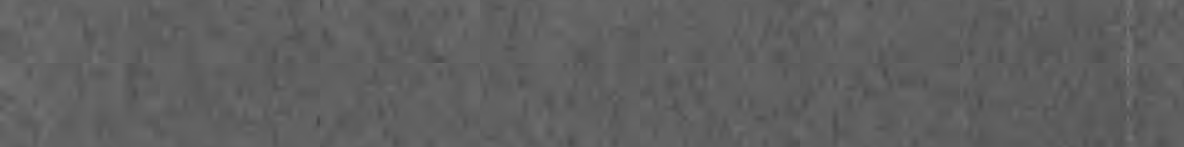

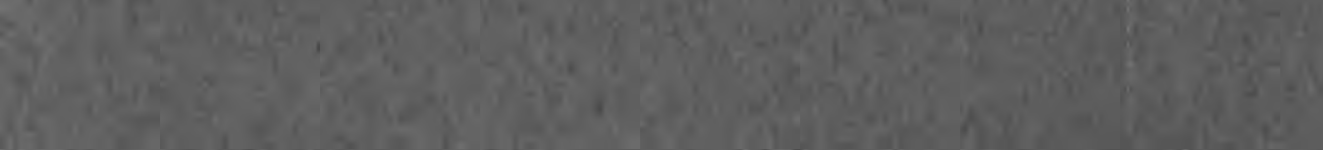

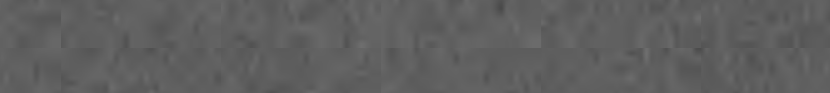

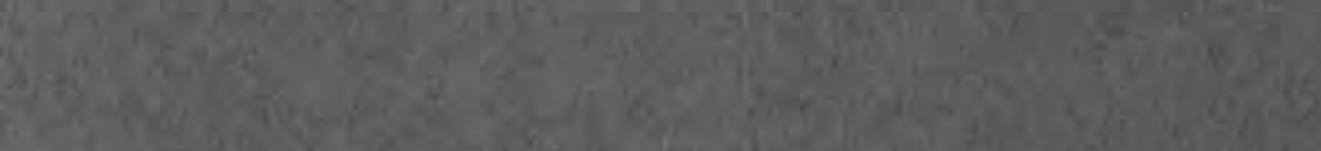

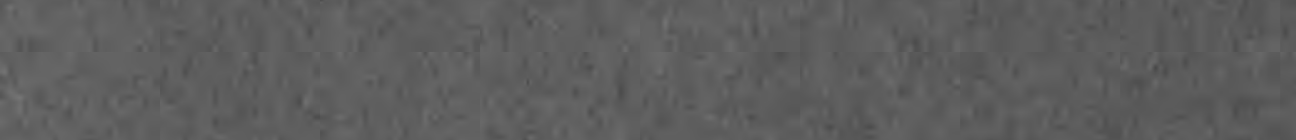

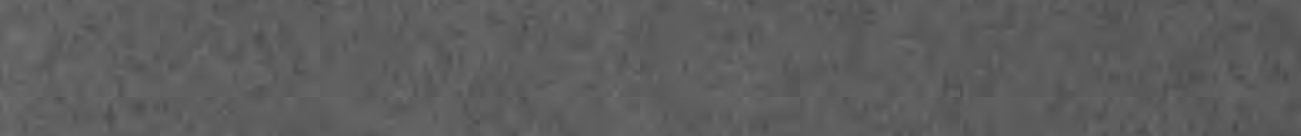

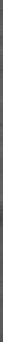

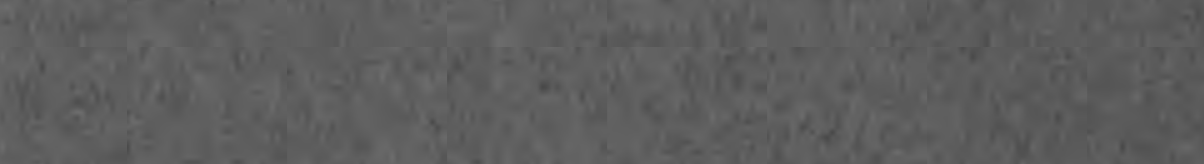

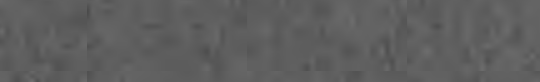
$\operatorname{lin}_{1}+1$

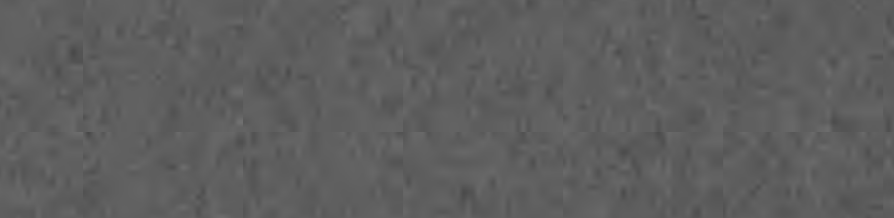

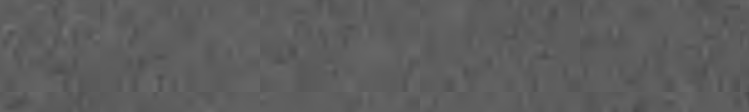

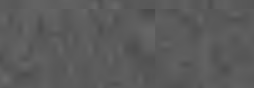

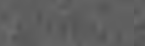
911.

28 1. 58

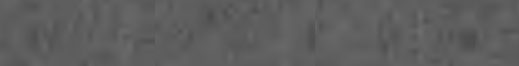

$$
\begin{aligned}
& \text { bix } x^{2}=18
\end{aligned}
$$

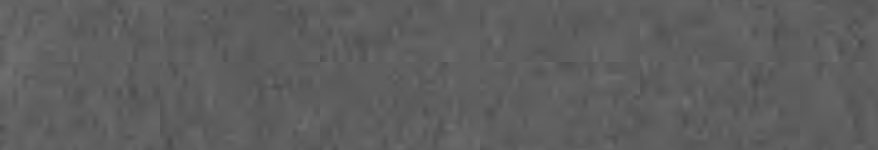

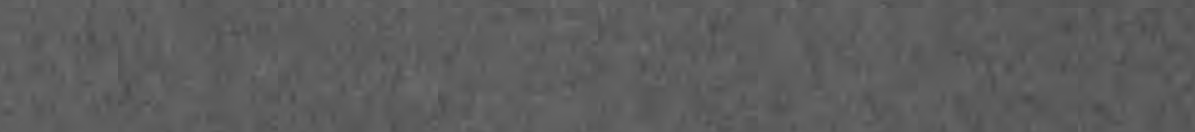
13.

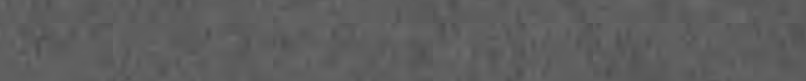

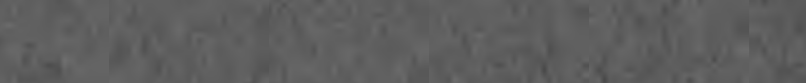

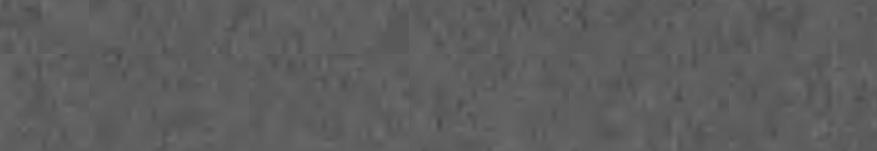

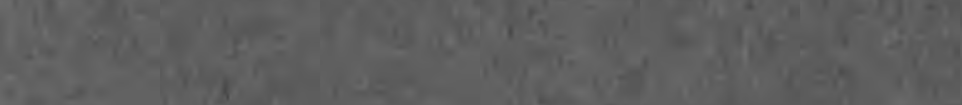

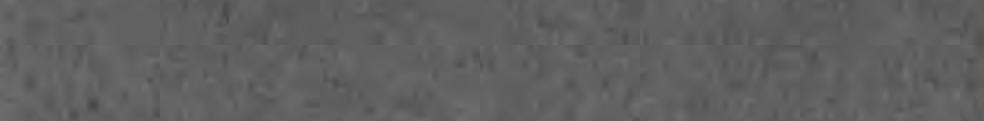
- 


\section{Geology of Majuba Hill Pershing County, Nevada}

By ALBERT F. TRITES, Jr., and RALPH H. THURSTON CONTRIBUTIONS TO THE GEOLOGY OF URANIUM GE OLOG I C A L S U R VEY B U L LE T I N 1046 -I

This report concerns work done on behalf of the U.S. Atomic Energy Commission and is published with the permission of the Commission

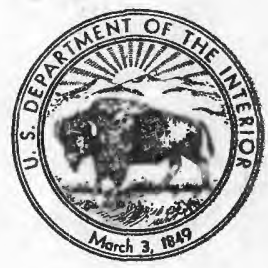




\section{UNITED STATES DEPARTMENT OF THE INTERIOR}

FRED A. SEATON, Secretary

GEOLOGICAL SURVEY

Thomas B. Nolan, Director Washington 25, D. C. 


\section{CONTENTS}

\begin{tabular}{|c|c|}
\hline & Page \\
\hline Abstract & 183 \\
\hline Introduction & 183 \\
\hline History and production & 185 \\
\hline Mine workings & 186 \\
\hline Geology & 186 \\
\hline Sedimentary rocks & 187 \\
\hline Argillite & 187 \\
\hline Quartzite & 187 \\
\hline Limestone & 188 \\
\hline Igneous rocks. & 188 \\
\hline Prerhyolite dikes and sills & 188 \\
\hline Rhyolitic rocks & 188 \\
\hline Earlier rhyolite & 189 \\
\hline Rhyolite porphyry & 189 \\
\hline Later rhyolite & 190 \\
\hline Breccias. & 190 \\
\hline Origin & 192 \\
\hline Talus, alluvium, and fanglomerate & 193 \\
\hline Structure & 193 \\
\hline Faults & 193 \\
\hline Fault breccias & 195 \\
\hline Hydrothermal alteration & 195 \\
\hline Ore deposits & 196 \\
\hline Copper & 196 \\
\hline Tin & 200 \\
\hline Uranium & 201 \\
\hline Suggestions for prospecting & 202 \\
\hline mmary & 203 \\
\hline terature cited & 203 \\
\hline
\end{tabular}

\section{ILLUSTRATIONS}

[Plates in pocket]

Plate 7. Geologic map and section of Majuba Hill.

8. Geologic map of surface above Middle adit level.

9. Geologic map of Upper and Middle adit levels and sections through Copper, No. 153, and Myler stopes.

'10. Geologic map of lower adit level.

11. Composite level and assay map.

Figure 25. Index map showing location of Majuba Hill 



\title{
CONTRIBUTIONS TO THE GEOLOGY OF URANIUM
}

\section{GEOLOGY OF MAJUBA HILL, PERSHING COUNTY, NEVADA}

\author{
By Albert F. Trites, Jr., and Ralph H. Thurston
}

\section{ABSTRACT}

Majuba Hill is a complex plug of rhyolitic rocks of Tertiary (?) age in the central part of the Antelope Range, Pershing County, Nev. The plug intrudes sedimentary rocks of Triassic (?) age, which consist chiefly of argillite with smaller amounts of quartzite and impure limestone. It is about 5,000 feet in diameter and has apophyses that extend beyond its margin. The rhyolitic rocks are of three varieties that are here called earlier rhyolite, rhyolite porphyry, and later rhyolite. Five main varieties of intrusive breccia occur in dikes and irregular masses cutting the older rhyolitic rocks. The rhyolitic rocks of the plug and the intruded sedimentary rocks have been silicified, sericitized, and tourmalinized.

Three principal preore faults are exposed in the Majuba Hill mine. The largest of these, the Majuba fault, strikes N. $30^{\circ}$ W., dips $54^{\circ}-84^{\circ} \mathrm{SW}$., and has a displacement of about 155 feet.

Copper and tin are the principal ore metals at Majuba Hill. From 1916 to 1949 slightly more than 27,000 tons of copper ore was produced from the Majuba Hill mine. About 350 tons of tin ore also has been shipped from this mine and small quantities of lead-silver and arsenic-silver ore have been produced from properties nearby. Uranium is locally associated with the copper and tin deposits in the Majuba Hill mine but has not been mined.

\section{INTRODUCTION}

Majuba Hill is in the Antelope (or Cedar) mining district, Pershing County, Nev., in the central part of the Antelope Range. The hill is about 20 miles west of Imlay, Nev., which is on the Southern Pacific Railroad and on Highway 40 (fig. 25) ; the hill is shown on the northcentral part of the Lovelock, Nev., quadrangle $1^{\circ}$ topographic map.

The Antelope Range is near the western margin of the Great Basin and is about 40 miles east of the Sierra Nevada. The range trends almost north and is about 22 miles long and 10 miles wide. It is flanked on the east and west by deep, alluvium-filled valleys. Majuba Hill, a prominent landmark in the range, rises to an altitude of 6,886 feet. 
The principal known ore deposits at Majuba Hill are in sec. 2, T. 32 N., R. 31 E., Mount Diablo base line and meridian (pl. 7), in the vicinity of the Majuba Hill mine. The deposits contain copper, tin, and uranium. A prospect in sec. 34, T. 33 N., R. 31 E., yielded a small

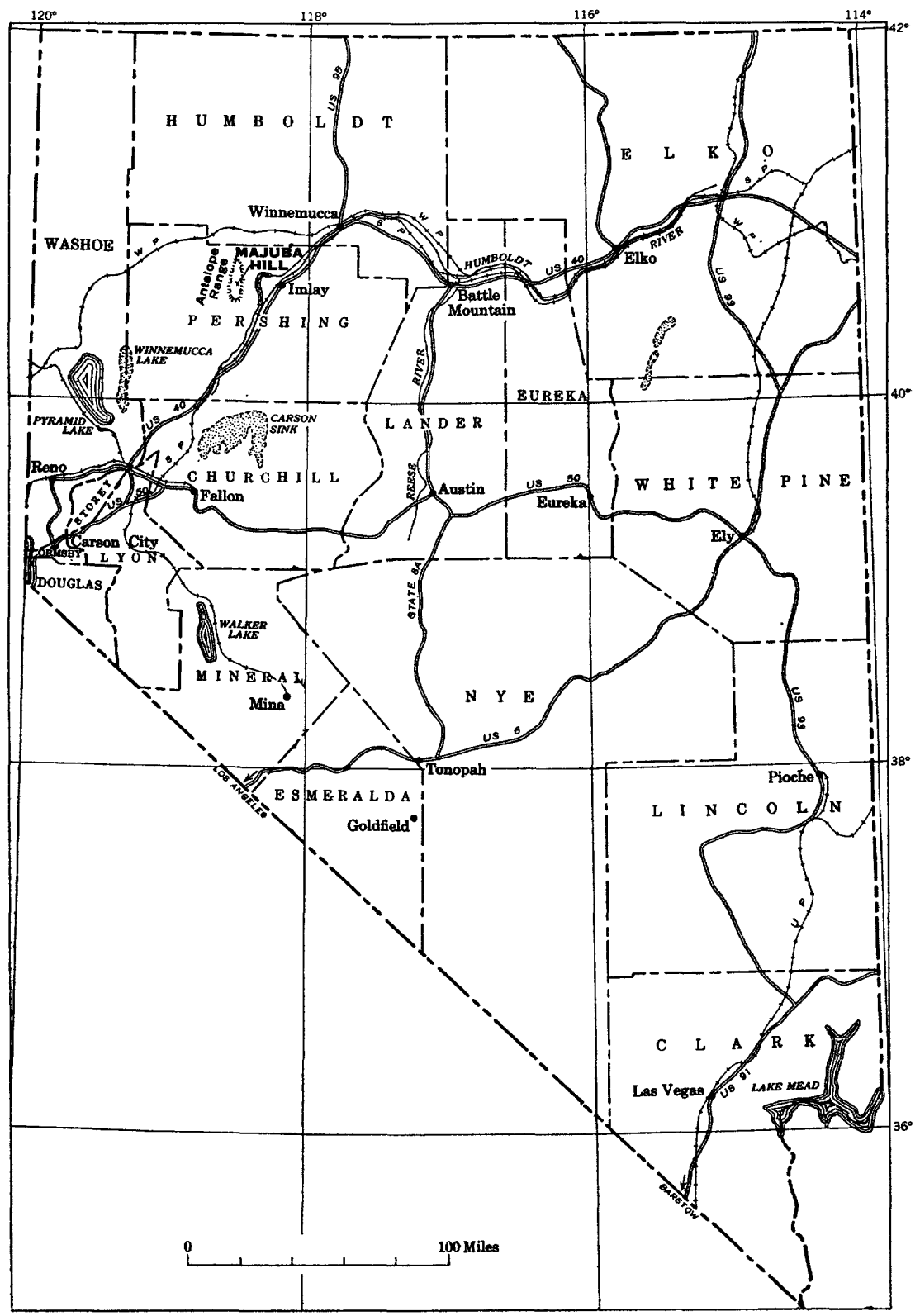

Frauga 25.-Index map showing location of Majuba Hill, Pershing County, Nev. 
amount of arsenic-silver ore during the early 1920's. Lead-silver ore has been produced from the Last Chance mine of the Majuba Fresno Mining Company, in sec. 1, T. 32 N., R. 31 E.

The tin and copper deposits at the Majuba Hill mine have been studied by Smith and Gianella (1942), and briefly examined in 1942 by James Gilluly and L. R. Page (written communication) and in 1945 by J. M. Wiese (written communication) of the U. S. Geological Survey. The U. S. Bureau of Mines conducted a drilling and drifting program in the deposit in 1943 (Matson, 1948). A brief reconnaissance examination of the mine for uranium was made in 1948 by Donald Wyant (written communication) of the U. S. Geological Survey.

Between January and June 1949 the writers made a more detailed study of the uranium deposits in the area as a part of the uranium investigations carried out by the U.S. Geological Survey on behalf of the Division of Raw Materials of the U. S. Atomic Energy Commission.

The geologic map and section by Smith and Gianella (1942), on a scale of 1 inch to 1,000 feet, were used as a base (pl. 7), and only the main area of intrusive rocks was remapped. A network of triangulation stations was established as a base of resection, stadia, and pace surveys. The underground workings were mapped on a scale of 1 inch to 20 feet, using Brunton bearings and chaining distances. The fieldwork was under the direction of Thurston; Trites prepared the manuscript and is thus responsible for many of the conclusions. The geologic maps and sections (pls. 7-10) were prepared by Thurston, assisted by Trites; most of the petrographic, mineralogic, and radiometric studies were made by Trites. Charles Milton identified several minerals from the Majuba Hill mine. Chemical analyses were made in the laboratories of the U. S. Geological Survey.

The writers are indebted to Mr. E. J. Myler, owner of the Majuba Hill mine, for assistance and many favors during this study.

\section{HISTORY AND PRODUCTION}

The uranium mineral torbernite (hydrous phosphate of copper and uranium) was reported in the copper deposit at Majuba Hill by Smith and Gianella (1942, p. 55) who state that many crystals were found in the Lower adit, 1,800 feet from the portal. The principal uranium deposit at the Majuba Hill mine was exposed between 1942 and 1945 during the mining of copper ore from the Copper stope.

Since about 1907 tin and copper minerals have been known to be present at Majuba Hill. Smith and Gianella (1942, p. 49) reported that in 1907 a single piece of cassiterite-bearing float was found on the hill although its source was not discovered. However, the Majuba Hill copper deposit was located in 1907 by A. J. McCauley, of Imlay 
(Matson, 1948, p. 2) and later was acquired by C. A. Copley and A. L. Gilmet. No work of importance was undertaken until 1914, when the property was operated by the Mason Valley Mines Company. This company has done most of the exploration work at the Majuba Hill mine, and between 1916 and 1918 produced about 4,000 tons of ore that contained 12 percent copper (Smith and Gianella, 1942, p. 41). In 1917 the Mason Valley company discovered a tin deposit underground during a search for copper ore.

The Mason Valley Mines Company ceased work in 1918 and, except for a small amount of work by A. J. McCauley who in 1928 shipped two cars of ore averaging 14 percent copper (Vanderburg, 1936, p. 10), the Majuba Hill mine remained idle until early in 1941 when the Freeport Sulphur Company obtained an option (Smith and Gianella, 1942, p. 41). This company conducted development work and core drilling to explore the tin-bearing zone but finally abandoned the project in October 1941.

The mine remained idle from 1941 until May 1942 when E. J. Myler acquired the property under a bond and lease arrangement with Harvey Reber who then owned the mine. In October 1942, after some exploratory work, Myler assigned a lease to J. O. Greenan and G. W. Kerr of Reno, Nev. Between October 1942 and May 1945, Greenan and Kerr mined about 23,000 tons of ore that had an average grade of about 4 percent copper (Matson, 1948, p. 1). The ore was purchased at the American Smelting and Refining Company smelter at Garfield, Utah. Greenan and Kerr also mined about 350 tons of ore that contained 2-4 percent tin (Matson, 1948, p. 1). This tin ore was milled at a tungsten concentrating plant at Toy, Nev., and was sold to the Metals Reserve Company at Battle Mountain, Nev. Greenan and Kerr relinquished their lease in May 1945. From May 1945 to May 1949, Myler mined a small quantity of copper ore.

\section{MINE WOREINGS}

The Majuba Hill mine workings are on three levels (pls. 9 and 10) at altitudes of 5,774, 6,250, and 6,451 feet. The Lower adit is 2,000 feet long and the Upper adit is about 100 feet long. The Middle adit workings have a total length of about 2,000 feet; almost all the ore produced by 1949 came from this level. A raise connects the Middle adit to the Upper adit.

\section{GEOLOGY}

The Antelope Range is made up of a thick section of argillite, limestone, and quartzite of Triassic(?) age. The Triassic(?) section is intruded by granitic stocks and plugs of late Mesozoic age, by rhyolitic 
rocks of Tertiary(?) age and by sills and dikes of andesite, dacite, iatite, and diorite of pre-Tertiary (?) age. The andesite, dacite, latite, and diorite are all older than the rhyolitic rocks of Tertiary (?) age. The sedimentary rocks also are cut by veins of quartz, most of which are barren and concordant with the bedding.

Majuba Hill, a conspicuous peak in the Antelope Range, is a complex plug about 5,000 feet in diameter that is composed of intrusive rhyolitic rocks and many diverse types of intrusive breccias. Repeated igneous intrusion and explosive activity have produced a very complex sequence of rocks. Irregular dikes of rhyolite porphyry extend for several thousand feet into the sedimentary rocks that surround the plug.

\section{SEDIMENTARY ROCKS}

The oldest rocks of Majuba Hill are metamorphosed sedimentary rocks of Triassic(?) age. These rocks are at least 5,000 feet thick and consist of more than 90 percent argillite and a few beds of quartzite and impure limestone. The beds strike northeast and dip from $50^{\circ}$ SE. to $50^{\circ} \mathrm{NW}$. (pl. 7). No fossils have been found in the sedimentary rocks; a Triassic age has been inferred by Smith and Gianella $(1942$, p. $42-43)$ on the basis of lithologic similarity to Triassic rocks in the Eugene Mountains, the next range east of the Antelope Range.

\section{ARGILLITE}

Argillite crops out over most of the area and is in contact with, or forms inclusions in, the intrusive rhyolitic rocks and breccias on the flanks of Majuba Hill. The argillite is thin bedded and ranges from dark blue to light gray. It is composed principally of clay minerals and quartz and subordinately of mica and scattered crystals of pyrite. In places the argillite has been altered to brown or red slate, phyllite, and hornfels for distances as much as 100 feet from intrusive rocks.

\section{QUARTZITE}

Lenticular beds of brown to buff, finely granular, micaceous, metamorphic quartzite constitute less than 1 percent of the sedimentary rocks. Individual beds range in thickness from a few inches to 6 feet and are seldom traceable along the strike for more than 100 feet. The beds weather to a reddish buff and may be distinguished easily from other rocks of the vicinity. The quartzite is made up principally of interlocking grains of quartz and a small number of grains of chert. The quartz grains have an average size of about $0.2 \mathrm{~mm}$ and have an undulating extinction. In quartzite beds near the rhyolite mass, tourmaline has been introduced and replaces some of the quartz grains. 


\section{LIMESTONE}

A few beds of gray medium-grained argillaceous limestone, as much as 3 inches thick, were intersected in the Lower adit level of the Majuba Hill mine. One 6-inch bed of calcite-epidote rock near a rhyolite porphyry dike is believed to represent an altered limestone bed.

\section{IGNEOUS ROCKS}

The igneous rocks of Majuba Hill ( $\mathrm{pl} .7$ ) consist of prerhyolite dikes and sills, and intrusive rhyolitic rocks of Tertiary (?) age. The writers have divided the rhyolitic rocks into three varieties on the basis of the abundance and sizes of phenocrysts. These are, from oldest to youngest, earlier rhyolite, rhyolite porphyry, and later rhyolite.

\section{PRERHYOLITE DIKES AND SILLS}

Dikes and sills of andesite, dacite, latite, and diorite of preTertiary (?) age are most abundant east and south of Majuba Hill. Outside the area mapped, fine-grained porphyritic to coarse-grained granite intrudes the sedimentary rocks. All of these igneous rocks form short lenticular sills that range in length from 1 to over 100 feet; they have an average thickness of 15 feet. Fresh surfaces of these rocks are grayish green to green; weathered surfaces are light tan or brown. A blocky to slightly platy jointing is well developed in them. Sericite, chlorite, calcite, and quartz occur as alteration products in many of these rocks. They are all believed to be older than the rhyolitic rocks of the Majuba Hill plug; fragments of them are contained as xenoliths in some of the rhyolitic rocks and many of the breccias of the plug.

\section{RFYOLITIC ROCKS}

The rhyolitic rocks of Tertiary(?) age, exclusive of the rhyolitic breccias, in order of their intrusion, are: earlier rhyolite, rhyolite porphyry, and later rhyolite. The distinguishing features of the three varieties are given below :

Rock $\quad \begin{gathered}\text { Grain size of } \\ \text { groundmass } \\ (\mathrm{mm})\end{gathered} \underset{\begin{array}{c}\text { Shenocrysts of } \\ (\mathrm{mm})\end{array}}{\begin{array}{c}\text { Abundance of } \\ \text { phenocrysts } \\ (\text { percent })\end{array}}$

Earlier rhyolite

0.02

$0.1-4.0$

2-10

Rhyolite porphyry

.05

. 2-5. 0

20-40

.05

.5

2-10

All the rhyolitic rocks are silicified and sericitized; the earlier rhyolite and the rhyolite porphyry are tourmalinized in the central parts of the Majuba Hill plug. 


\section{EARIIER RHYOIITE}

The earlier rhyolite forms large outcrops on the crest of the hill and has been penetrated by the three adits of the Majuba Hill mine. The earlier rhyolite is cut by the later rhyolite, rhyolite porphyry, and many of the breccias and occurs as inclusions in both the later rhyolite and breccias. It contains inclusions of argillite and quartzite, as much as 4 inches wide, especially near its contacts with the sedimentary rocks.

The earlier rhyolite is a light-gray rock, but it is light tan or brown where weathered, nearly white to light gray where it is silicified or sericitized, and mottled gray and black where it is intensely tourmalinized. From 1 to 7 percent of the rock is quartz phenocrysts, 1 to 3 percent sanidine phenocrysts, and less than 2 percent plagioclase phenocrysts. The phenocrysts range in length from 0.1 to $4 \mathrm{~mm}$, the average being about $2 \mathrm{~mm}$. The quartz phenocrysts are characteristically welldeveloped, doubly terminated crystals. The groundmass consists mainly of quartz, sanidine, and sericite and has an average grain size of about $0.02 \mathrm{~mm}$.

\section{RHYOLITE PORPHYRY}

The rhyolite porphyry forms an irregular mass within the plug of Majuba Hill where it constitutes about 15 percent of the total igneous rock exposed. Sills and dikes of rhyolite porphyry occur in the surrounding argillite. Some of the larger dikes (pl. 7) are wider in the argillite than in the plug.

The contacts of the rhyolite porphyry with the argillite and the earlier rhyolite are sharp, and the rhyolite porphyry shows only a slight amount of chilling. These contacts are irregular and dip vertically or steeply to the southeast. Where the rhyolite porphyry is in contact with some of the larger masses of breccias, it fingers into the breccia, forming an irregular contact zone.

The rhyolite porphyry contains xenoliths of argillite, earlier rhyolite, and rhyolite-bearing breccias. A few rhyolite porphyry dikes are separated from the earlier rhyolite by rims of rhyolite-bearing breccias.

The freshly exposed rhyolite porphyry is light gray; it is white or very light gray where bleached, or dark gray to mottled gray and black where tourmalinized. The rock contains 20 to 40 percent phenocrysts, which are 0.2 to $5 \mathrm{~mm}$ wide and are mainly quartz with smaller quantities of sanidine and plagioclase. These phenocrysts are set in a groundmass of quartz, sanidine, and plagioclase having a grain size of about $0.05 \mathrm{~mm}$. Many of the quartz phenocrysts are present in the fine-grained groundmass as double bipyramidal crystals. The rhyolite porphyry is distinguished from the earlier rhyolite by a larger number of phenocrysts and a slightly coarser groundmass. 


\section{IATER RHYOIITE}

The later rhyolite crops out over a large area along the southeastern margin of the rhyolitic plug where it contains large xenoliths of earlier rhyolite and breccia, but has not been penetrated in the Majuba Hill mine workings. All observed contacts between the later rhyolite and other rocks dip $80^{\circ}$ or more. The later rhyolite has been fractured by closely spaced joints which have produced a bricklike rubble surface on many exposures.

The typical unaltered rock is white or light yellow on both fresh and weathered surfaces and is generally lighter in color than the other rhyolitic rocks in the area. The later rhyolite has smaller phenocrysts than either the earlier rhyolite or the rhyolite porphyry. The phenocrysts in the later rhyolite are of quartz, sanidine, and plagioclase. They average $0.5 \mathrm{~mm}$ in diameter and constitute from 2 to 10 percent of the rock. The groundmass has a grain size of about $0.05 \mathrm{~mm}$.

Much of the later rhyolite has been sericitized; secondary quartz has been introduced locally, but silicification is less characteristic of the later rhyolite than of the earlier rhyolite and the rhyolite porphyry. Although tourmalinized xenoliths of the earlier rhyolite and rhyolite porphyry are present in the later rhyolite, the later rhyolite has not been tourmalinized.

\section{BRECCIAS}

Dikelike bodies of breccias composed of chaotic mixtures of rubbly material occur throughout the rhyolitic plug. These breccias contain fragments of the sedimentary rocks and of both the earlier rhyolite and rhyolite porphyry. The fragments range in size from a fraction of an inch to 9 feet; fragments of rhyolitic rocks are commonly rounded, but those of argillite are sharply angular and of smaller sizes. Some of the more salient features of the breccias are listed below:

1. The breccias occur both as regular and irregular dikes and as irregular masses at dike intersections. The dikes range in length from 10 to more than 1,000 feet and in width from 4 inches to 60 feet.

2. The breccias trend in diverse directions and dip nearly vertically. Some of the dikes, especially those near the outer rim of the plug, have an arcuate or circumferential pattern. The breccia dikes near the center of the plug have a predominant $\mathrm{N} .30^{\circ}-40^{\circ} \mathrm{W}$. trend and are parallel or almost parallel to the Majuba fault, a large postrhyolite structure exposed in the workings of the Majuba Hill mine. Many other breccia dikes within the plug trend $\mathrm{N} .5^{\circ}-15^{\circ} \mathrm{E}$., or $\mathrm{N} .70^{\circ}-85^{\circ} \mathrm{H}$. roughly at $45^{\circ}$ to the major trend.

3. The breccias contain heterogeneous assemblages of well-rounded to angular fragments of all rocks cut by them. The longer axes of many of the angular fragments are oriented parallel to the dip of the contact, but the kind of fragments does not necessarily conform to the wall rock. 
4. At least three, and possibly as many as five, different ages of breccias have been determined. The formation of all, except perhaps the last, of these breccias was followed by the injection of rhyolitic rocks.

5. The contacts of the breccia dikes with the rhyolitic rocks range from regular to very irregular. The contacts are relatively sharp where the breccia is in contact with argillite or prebreccia rhyolite and gradational where the breccia is in contact with postbreccia rhyolite which has sent apophyses into the breccia.

6. Rhyolitic rock has been locally injected into some of the earlier breccias, filling the spaces between the fragments. There seems to be a complete gradation between breccias with such a rhyolitic groundmass and rhyolitic rocks with abundant xenoliths.

7. Many of the breccias have been silicified, sericitized, and tourmalinized.

Five main varieties of breccia have been distinguished. These five varieties, classified according to rock fragments, are : Breccia 1 , composed principally of fragments of argillite; breccia 2, composed principally of fragments of earlier rhyolite; breccia 3, composed of fragments of argillite and earlier rhyolite; breccia 4, composed of fragments of argillite, earlier rhyolite, and rhyolite porphyry; and breccia 5, composed of fragments of earlier rhyolite and rhyolite porphyry. The distribution of the breccias is so complex that the individual varieties are not shown on the surface or underground maps.

The order of formation of rhyolitic rocks and breccias of Tertiary (?) age at Majuba Hill is believed to be as follows:
1. Breccia 1 (oldest)
5. Rhyolite porphyry
2. Earlier rhyolite
6. Breccia 4
3. Breccia 2
7. Breccia 5
4. Breccia 3
8. Later rhyolite (youngest)

Breccia 1.-The argillite breccia occurs as discontinuous segments that are as much as 100 feet wide near the contacts of the earlier rhyolite of the plug with argillite wall rock. The rock ranges from white or light gray to dark blue or black, and consists of fragments of argillite with minor amounts of quartzite, limestone, prerhyolite quartz veins, and earlier rhyolite. Earlier rhyolite and rhyolite porphyry have been injected locally into breccia 1.

Breccia 2.-The fragmental constituents of breccia 2 are subrounded, have a maximum size of 5 inches, and are dominantly of earlier rhyolite. Breccia 2 is exposed near the northeast part of the summit of Majuba Hill. A large part of breccia 2 has been injected by rhyolite porphyry and is intensely silicified and sericitized but not tourmalinized.

Breccia 3.-Fragments of both argillite and earlier rhyolite compose breccia 3, which is the most abundant and widespread breccia at Majuba Hill. At the Majuba Hill mine it forms dikes that cut argillite and an interconnecting network that cuts the earlier rhyolite of the plug. The breccia is light gray to white and contains fragments of 
argillite and earlier rhyolite in varying proportions. Locally breccia 3 has been injected by earlier rhyolite and rhyolite porphyry, and the rock generally has been silicified, sericitized, and tourmalinized.

Breccia 4.-Fragments of argillite, earlier rhyolite, and rhyolite porphyry constitute breccia 4 . This breccia forms the largest dikes in the area and has been cut in all the stopes of the Majuba Hill mine. The dikes exposed in the mine workings trend from north to northeast and dip from $7^{\circ}$ to $80^{\circ}$ east or southeast. A prominent outcrop of breccia 4 immediately north of the Upper adit is about 195 feet long and as much as 75 feet wide. This exposure of breccia is bounded on all sides by faults ( $\mathrm{pl} .8$, coordinates $1800 \mathrm{~N}$. and $400 \mathrm{~W}$.). Breccia 4 has been intensely tourmalinized, as well as silicified and sericitized.

Breccia 5.-Fragments of earlier rhyolite and rhyolite porphyry predominate in breccia 5 , which crops out in an irregular area of about 2,500 square feet near the center of the plug. The rock is mottled black and white, and has weathered to a rubble of rounded fragments. It has been silicified, sericitized and tourmalinized.

\section{ORIGIN}

Many of the breccias are believed to have been formed by gases attendant with the intrusion of the rhyolitic rocks in the plug. Breccia 1 (argillite breccia) which surrounds much of the plug may have been formed during the initial explosive action, and a large number of the breccia dikes probably represent material that was pushed ahead of the advancing rhyolite. The chaotic nature of many of the breccias and the large range in size of fragments further suggest that explosive action was responsible for their origin. The lack of gradation between many of the breccias into the argillite country rock and earlier formed rhyolitic rocks, with little evidence of plucking along the walls, also suggests vigorous activity.

The main body of earlier rhyolite was injected following the initial brecciation of the argillite, but the presence of some fragments of earlier rhyolite in breccia 1 indicates that part of this rhyolite had solidified prior to the explosive activity. This rhyolite perhaps assimilated many of the shattered, displaced rocks and filled the interstices of much of the breccia 1. The vertical direction of flow and gaseous activity is suggested by the vertical orientation of xenoliths along the edges of the rhyolite dikes and by the nearly vertical walls of the breccia dikes.

Following the injection of the earlier rhyolite, another period of gaseous activity may have ensued during which some of the earlier rhyolite was brecciated and breccias 2 and 3 were formed. A second pulse of rhyolitic magma then injected the rhyolite porphyry in the form of dikes and masses which cut the earlier rhyolite and locally impregnated the three earlier formed breccias. Apparently a third 
main period of gaseous activity followed the injection of the rhyolite to form breccias containing fragments of rhyolite porphyry (breccias 4 and 5). This was apparently the last step of violent brecciation activity and was followed by the injection of the later rhyolite on the southeast side of the hill.

Burbank (1941, p. 170-178) believes that the passage of hot juvenile gases along joints or fissures formed many of the volcanic pipes of the Red Mountain district, Colorado. These volcanic emanations blowpiped their way upward, locally brecciating the rock as they moved and producing cylindrical-shaped bodies of breccia. While such action may have occurred in the formation of the breccias at Majuba Hill, the dikelike shapes of the breccia bodies and their heterogeneousness would seem to negate the importance of such gaseous action.

\section{TALUS, ALLUVIUM, AND FANGLOMERATE}

Unconsolidated deposits of talus, alluvium, and fanglomerate of Quaternary age overlie much of the bedrock at Majuba Hill. Talus occurs on the steeper slopes of the hill itself, covering much of the rhyolitic rocks and grading into fanglomerates near the base of the hill. Alluvium occurs in patches along the stream valleys on the north and south sides of the hill.

\section{STRUCTURE}

The sedimentary rocks of Triassic(?) age strike generally $\mathrm{N}$. $45^{\circ}-70^{\circ} \mathrm{E}$., and dip $50^{\circ}-90^{\circ} \mathrm{NW}$, except in the southwest quarter of the area (pl. 7) where the rocks strike from N. $5^{\circ}$ W. to N. $25^{\circ} \mathrm{E}$. and $\operatorname{dip} 75^{\circ} \mathrm{SW}$. or $60^{\circ}-90^{\circ} \mathrm{NW}$. Locally the rocks are highly crumpled and overturned near contacts with igneous rock. The argillites are intruded by all the igneous rocks and contain concordant quartz veins.

The dominant structural feature is the rhyolitic plug, roughly 5,000 feet in diameter, containing dikes and irregular masses of breccia. Rhyolite porphyry dikes extend across the earlier rhyolite into the argillite to the northeast and southwest beyond the margin of the plug, and later rhyolite occurs as an irregular body along the southeast margin of the plug.

\section{FAULTS}

Three main faults, the Majuba fault, the No. 211 fault, and the Myler fault, are exposed in the Majuba Hill mine. The Majuba fault is exposed in each of the three levels (pls. 9 and 10) and may crop out at one place on the surface above the mine workings. The fault strikes N. $30^{\circ}$ $\mathrm{W}$. and $54^{\circ}-84^{\circ} \mathrm{SW}$; its fault gouge and breccia zone thickens from less than 3 feet at the surface and in the Upper adit to 10 feet in 
the Lower adit. According to Smith and Gianella (1948, p. 48), the displacement along the Majuba fault is between 30 and 150 feet. They say:

In the drift that extends northwestward along the fault from the end of the west crosscut on the lowest level *** flutings show that the hanging wall moved obliquely downward and southward at an angle diverging $35^{\circ}$ from a line pointing straight down the dip. The amount of displacement in this direction is certainly over 30 feet but probably less than 150 feet, as indicated by the contact between slate and rhyolite porphyry that is exposed in the footwall, east on the east side of the drift.

The writers believe that fault 211 has been displaced by the Majuba fault as shown in plate 9. The displacement of this fault measured along the Majuba fault is about 155 feet. The Majuba fault has been displaced in the Middle adit level by a nearly parallel fault which is exposed in drift 201-N and in crosscuts 215 and 217 (pl. 9). The west side of the Majuba fault has been moved 70 feet northward relative to the east side along the fault. The Majuba fault has apparently been terminated at its south end by a cross-fault exposed in drift 201-S. Although the Majuba fault may have been displaced rather than terminated along this cross-fault, such a faulted segment has not been found in either drift 201-S or the Middle adit. The Majuba fault zone pinches north of crosscut 215 where it continues as a much smaller fault beyond the end of drift 201-N.

The Majuba fault is believed to have been formed before the introduction of copper, tin, and uranium minerals, because primary sufides have been found in the gouge along the fault. Unbroken crystals of tourmaline appear to substantiate this premineralization movement along the fault.

Fault 211 is exposed in the Middle adit level about 390 feet from the portal, in crosscut 211 about 20 feet east of the adit, and at the head of the "G" raise about 53 feet above the adit level. A fault which is exposed beneath the Copper stope in the sublevel 43 feet below the Middle adit level (pl. 9) is believed to be a segment of fault 211 displaced downward by the Majuba fault.

A fault, called the Myler fault, is exposed only in the Myler stope (pl. 9) where it has about 4 feet of gouge and fault breccia. This fault strikes N. $5^{\circ}-20^{\circ}$ W. and dips $60^{\circ}-63^{\circ} \mathrm{SW}$. As the Myler fault does not occur in crosscut 211 , it is inferred to end against fault 211 about 30 feet above crosscut 211 (section $A-A^{\prime}$, pl. 9).

Several diversely oriented faults having small displacements are widely distributed within the plug. A few of these faults can be traced beyond the periphery of the plug, but do not extend for more than 100 feet into the surrounding argillites. 
Fault movement may have taken place at intervals over a considerable period of time. It is believed that there was movement on all the faults after the intrusion of the three rhyolitic rocks and the five breccias. The fault zones are sharply defined in the earlier rhyolite and the rhyolite porphyry and are less obvious in dikes and masses of breccias. The main component of the movement was vertical, and the principal faulting is believed to have resulted from the readjustment of the rocks of the plug after intrusion and explosion had ceased.

\section{FAULT BRECCIAS}

Breccias that range in thickness from $1 / 4$ inch to 10 feet, and that contain fragments of all the rocks cut by the faults, are exposed along many of the faults at Majuba Hill. Individual breccia fragments range in diameter from $1 / 16$ to 8 inches, and most of the fragments are sharply angular. Sericite and kaolinite are commonly abundant in the gouge associated with the breccia; quartz and tourmaline have been introduced locally.

\section{HYDROTHERMAL ALTERATION}

Hydrothermal alteration, associated with the rhyolitic rocks and breccias, has affected the rocks in the plug as well as the argillites surrounding the plug. The three major types of alteration, from oldest to youngest, are silicification, sericitization, and tourmalinization.

Silicification is believed to have been the first and most widespread alteration and was apparently of two or more stages. Granular quartz has filled many cavities formed by the leaching of sanidine and plagioclase phenocrysts of the rhyolitic rocks; quartz and sericite form the matrix of some of the altered rhyolite. Veinlets of later quartz locally cut the quartz-sericite groundmass in some of the earlier rhyolite.

Sericitization has affected all of the rhyolitic rocks of Majuba Hill. Sericite constitutes 30 to 60 percent of the groundmass of many of the altered rhyolitic rocks and is abundant in intrusive breccia and in the argillite adjacent to rhyolitic rocks. Sericite has replaced many of the phenocrysts of plagioclase and sanidine, quartz in feldspar voids, and feldspar and quartz of the groundmass.

Tourmalinization has been most intense near the breccias; tourmaline is abundant in the rhyolite porphyry and in the breccias, less abundant in the earlier rhyolite, and apparently absent in the later rhyolite. Irregular grains, needles, and rosettes of tourmaline, as much as $2 \mathrm{~mm}$ across, incompletely fill the voids left in the rhyolitic rocks by leaching of the feldspar phenocrysts. A mixture of quartz and tourmaline completely fills some of these voids. The tourmaline 
in the intrusive breccias forms grains and rosettes as much as 5 inches in greatest dimension.

Prisms of epidote have formed in the alteration of beds of impure limestone near the rhyolitic rocks of the plug. One bed of calcite and epidote cut by the Lower adit is believed to be such an altered limestone. Zoisite is an alteration product in some of the altered argillite and breccia. The zoisite is in the form of microscopic prismatic crystals that are grouped together in bundles replacing the fragments of the breccias and the clay minerals of the argillite.

\section{ORE DEPOSITS}

The principal ore deposits at Majuba Hill are those of copper, tin, and uranium exposed in the Majuba Hill mine. The arsenic-silver deposit in sec. 34, T. 33 N., R. 31 E., was inaccessible at the time of the writers' visit and will not be discussed in this report. The lead deposit at the Last Chance mine was examined for uranium but was not studied in detail because no abnormal radioactivity was found.

All samples collected at the Majuba Hill mine contain some gold and silver. The gold content was invariably low, ranging from a trace to 0.05 ounce per ton; silver ranged from 0.10 to 11.08 ounces per ton in individual samples. The highest grade silver-bearing rock is in the breccia exposed in the stope 211. Spectrographic analyses of samples are shown in the table on pages 198-199.

\section{COPPER}

Copper ore has been mined from the Copper, Myler, and No. 153 stopes of the Middle adit level. Smith and Gianella (1942, p. 54) stated that the 4,000 tons of 12 percent copper ore mined in 1915-18 came from a large stope above and a small stope below the Middle adit. In this report the large stope is called the Copper stope, and the small stope 43 feet below the Middle adit level is called the sublevel. A large part of the 23,000 tons of copper ore of slightly less than 4 percent copper produced in 1942-45 (Matson, 1948, p. 1) is believed to have been mined from the Copper and No. 153 stopes. A small amount of copper ore was produced in 1949 from the Myler stope. Mining has left only small remnants of ore in all except the Myler stope.

The copper ore bodies have been formed by the enrichment of copper in a relatively narrow zone beneath an oxidized zone. The primary copper sulfide minerals have been leached near the surface and copper has been enriched by supergene processes beneath the oxidized zone. The zones of oxidation and enrichment are not well defined. Complete oxidation extends to about 60 feet below the surface, but some oxida- 
tion extends to the greatest depth of exploration, nearly 1,000 feet. The supergene enrichment zone extends from the oxidized zone to a maximum depth of slightly more than 200 feet below the surface.

\section{MINERALOGY}

Most of the copper ore is composed of chalcocite with smaller amounts of chalcopyrite and cuprite. Abundant azurite, brochantite, malachite, chalcanthite, and chrysacolla occur locally in the upper parts of some of the ore bodies. The principal metallic gangue minerals associated with the chalcocite are arsenopyrite and pyrite; nonmetallic gangue minerals include quartz, iron oxides, and tourmaline. Locally chalcocite is associated with cassiterite and metazeunerite.

The hypogene copper sulfide chalcopyrite in association with the other hypogene minerals arsenopyrite and pyrite occurs as scattered specks in much of the ore. Arsenopyrite is notably abundant in the copper- and tin-bearing vein in the Copper stope. Charles Milton (1950, written communication) found that the arsenopyrite was distinguished readily by its brilliant silvery-white color, hardness, and strong anisotropy. Small anhedra of pyrite are widely scattered through the copper ore bodies.

Chalcocite is the most abundant copper mineral in the Majuba Hill mine and is of supergene origin. Much of the chalcocite is in fissures in chalcopyrite, arsenopyrite, and pyrite. Milton found the chalcocite to be gray with a bluish tint in reflected light and apparently isotropic. Smith and Gianella (1942, p. 54) have reported that small amounts of covellite are associated with the chalcocite.

The oxidized copper minerals cuprite, azurite, brochantite, malachite, chalcanthite, and chrysacolla occur with the iron oxides in the oxidized zone and the upper part of the supergene zone. Cuprite is especially abundant in the breccia exposed in the Myler stope. Columns of blue chalcanthite crystals have formed efflorescent coatings on many of the walls of the Copper stope, and emerald green crystals of brochantite have been deposited in some of the breccias and fault gouge.

Scorodite, olivenite, and chalcophyllite have been reported by Smith and Gianella (1942, p. 55). The scorodite, a hydrous ferric arsenate, occurs locally with the oxidized copper minerals. It is abundant in the winze at the Tin stope where it has formed thin green to brown coatings on altered earlier rhyolite. Olivenite, a basic copper phosphate, has formed dark-green crusts and microscopic veinlets in the rock in many places in the two upper levels. Some of the olivenite is in felted masses of extremely small acicular crystals. Larger crystals are bright green under the microscope and are doubly terminated. 
1.--Semiquantitive spectrographic analyses of sam [Analytical data are visual estimates and indicate these relative orders of magnitude: (10) 10 percent percent. " 0 " indicates element looked for but not found. No thorium was

\begin{tabular}{|c|c|c|c|c|c|c|}
\hline $\begin{array}{l}\text { Field } \\
\text { No. }\end{array}$ & Location & Rock & $\begin{array}{l}\text { Type of } \\
\text { sample }\end{array}$ & $\mathrm{SiO}_{2}$ & $\mathrm{Al}_{2} \mathrm{O}_{3}$ & $\mathrm{Fe}_{2} \mathrm{O}_{3}$ \\
\hline$T-5$ & Chute from stope $211 \ldots$ & Tin-bearing breccia 4 & Grab........... & 10 & 10 & 10 \\
\hline-6 & Do & - do do...... & ....do-.......... & 10 & 10 & 10 \\
\hline-7 & Raise 211 & - & $\ldots \mathrm{do}$ & 10 & 10 & 10 \\
\hline-8 & Southwest wall of drift 202_- & Uranium-bearing argillite_. & 6-foot channel_ & 10 & 10 & 1.0 \\
\hline-9 & Do & $\begin{array}{l}\text { Copper-and uranium-bearing } \\
\text { rhyolite porphyry. }\end{array}$ & $\begin{array}{l}\text { 12-foot } \\
\text { channel. }\end{array}$ & 10 & 10 & 1.0 \\
\hline-10 & Southeast wall of drift 202 & - do & $\begin{array}{l}\text { 14-foot } \\
\text { channel. }\end{array}$ & 10 & 10 & 10 \\
\hline-11 & Southwest wall of drift 202 & - do & 8-foot channel. & 10 & 10 & 10 \\
\hline-12 & South wall of crosscut 216 & do & 6-foot channel. & 10 & 10 & 10 \\
\hline-13 & $\begin{array}{l}\text { Northwest wall of Myler } \\
\text { stope. }\end{array}$ & Copper-bearing breccia 4. & Bulk............ & 10 & 10 & 10 \\
\hline-14 & Southeast wall of stope 211 .. & Tin-bearing breccia 4 & 8-foot channel. & 10 & 10 & 10 \\
\hline-15 & Southwest wall of stope 211 & $\begin{array}{l}\text { Copper-bearing rhyolite por- } \\
\text { phyry. }\end{array}$ & $\begin{array}{l}\text { 15. foot } \\
\text { channel. }\end{array}$ & 10 & 10 & 10 \\
\hline-16 & South wall of Myler raise... & Copper-bearing breccia 4 & 5-foot channel. & 10 & 10 & 10 \\
\hline-17 & Do & - do & 6-foot channel. & 10 & 10 & 10 \\
\hline-18 & South wall of Copper stope.- & $\begin{array}{l}\text { Copper-bearing rhyolite por- } \\
\text { phyry. }\end{array}$ & 3-foot channel & 10 & 10 & 10 \\
\hline-19 & Do. & - do & $\begin{array}{l}\text { 10-foot } \\
\text { channel. }\end{array}$ & 10 & 10 & 10 \\
\hline-20 & Do & do & $\begin{array}{l}\text { 12-foot } \\
\text { channel. }\end{array}$ & 10 & 10 & 10 \\
\hline-21 & Do & $\begin{array}{l}\text { Copper- and uranium-bearing } \\
\text { vein. }\end{array}$ & 3-foot channel & 10 & 10 & 10 \\
\hline-22 & $\begin{array}{l}\text { Northwest wall of Copper } \\
\text { stope. }\end{array}$ & Copper-bearing breccia 4. & $\begin{array}{l}\text { 10-foot } \\
\text { channel. }\end{array}$ & 10 & 10 & 10 \\
\hline-23 & South wall of crosscut 218 & Rhyolite porphyry & 9-foot channel & 10 & 10 & 10 \\
\hline-24 & Tin stope & Tin-bearing breccia 4 & Bulk_............ & 10 & 10 & 10 \\
\hline-25 & East wall of stope 153 & Copper-bearing breccia 4....- & -....do-.......... & 10 & 10 & 10 \\
\hline-26 & Do & - do & 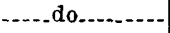 & 10 & 10 & 10 \\
\hline-27 & Chute from $\mathbf{K}$ raise. .......... & $\begin{array}{l}\text { Copper-bearing rhyolite por- } \\
\text { phyry. }\end{array}$ & Grab........... & 10 & 10 & 10 \\
\hline
\end{tabular}

Chalcophyllite, a hydrous copper arsenate of variable composition, occurs locally with malachite and azurite in the Middle adit level. The mineral has a platy habit and superficially resembles metazeunerite; the crystals have an excellent basal cleavage. Milton found the chalcophyllite to be optically negative, uniaxial, with moderate birefringence and drab greenish-yellow and bright bluish-green dichroism.

The clinoclase, a copper arsenate, at the Majuba Hill mine has been described by Gianella (1946). The mineral is associated with malachite, azurite, olivenite, and hydrated oxides of iron; it occurs in dark blue-green radiating crystals as much as $6 \mathrm{~mm}$ long, as tufts of small crystals, and as drusy incrustations in fractures in tourmalinized rhyolite. 
ples, Majuba Hill mine, Pershing County, Neo.

or more; (1.0) 1 to 10 percent; (0.1) 0.1 to 1 percent; (0.01) 0.01 to 0.1 percent; and (0.001) 0.001 to 0.01 observed in any of the samples. Analyses by the U.' 8 . Geological Survey.]

\begin{tabular}{|c|c|c|c|c|c|c|c|c|c|c|c|c|c|c|c|}
\hline $\mathrm{CaO}$ & $\mathrm{MgO}$ & Ag & $\mathrm{B}_{2} \mathrm{O}_{3}$ & $\mathrm{Bi}_{2} \mathrm{O}_{3}$ & $\mathrm{CO}_{3} \mathrm{O}_{4}$ & $\mathrm{Cr}_{2} \mathrm{O}_{3}$ & $\mathrm{Cu}$ & $\mathrm{MnO}$ & $\mathrm{MoO}$ & $\mathrm{PbO}$ & $\mathrm{SnO}_{2}$ & $\mathrm{TiO}_{2}$ & $\mathrm{~V}_{2} \mathrm{O}_{3}$ & $\mathrm{ZnO}$ & $\mathrm{ZrO}_{2}$ \\
\hline 0.1 & 1.0 & 0.1 & 1.0 & 0.01 & 0 & 0 & 1.0 & 0.1 & 0.001 & 0 & 0.1 & 0.1 & 0.01 & 0 & 0.1 \\
\hline .1 & 1.0 & .1 & 1.0 & .01 & 0 & 0 & 1.0 & .1 & .001 & 0 & 1.0 & .1 & .01 & 0 & .1 \\
\hline .1 & .1 & .1 & 1.0 & .01 & 0 & 0 & 1.0 & .1 & .001 & 0 & 1.0 & .1 & .01 & .001 & .1 \\
\hline .1 & 1.0 & .01 & 1,0 & .001 & 0 & .001 & .1 & .1 & & 0 & .01 & 1.0 & .1 & .001 & .1 \\
\hline .1 & 1.0 & .01 & 1.0 & .001 & 0 & 0 & .1 & .1 & .001 & 0 & .1 & 1.0 & .01 & 0 & .1 \\
\hline .1 & 1.0 & .01 & 1.0 & .01 & 0 & 0 & 1.0 & .1 & .001 & 0 & .01 & 1.0 & .01 & .001 & .1 \\
\hline .1 & 1.0 & .01 & 1.0 & .01 & 0 & 0 & 1.0 & .1 & .001 & 0 & .01 & 1.0 & .001 & .001 & .01 \\
\hline .1 & 1.0 & .001 & 1.0 & 0 & 0 & .001 & .1 & .1 & .001 & 0 & .01 & 1.0 & .01 & 0 & .1 \\
\hline 1.0 & 1.0 & .01 & .1 & 0 & .01 & .01 & 1.0 & .01 & .01 & .01 & .01 & .1 & .001 & 0 & .01 \\
\hline 0 & 1.0 & .1 & .1 & .001 & 0 & 0 & 1.0 & .01 & .001 & 0 & .01 & .1 & .001 & 0 & .01 \\
\hline 0 & 1.0 & .001 & .1 & 0 & .01 & .001 & 1.0 & .01 & .001 & 0 & .01 & .1 & .001 & 0 & .01 \\
\hline .1 & 1.0 & .01 & .1 & 0 & .01 & 0 & 1.0 & .01 & .001 & 0 & .01 & .1 & .001 & 0 & .01 \\
\hline .1 & 1.0 & .001 & .1 & 0 & 0 & 0 & 1.0 & .01 & .001 & 0 & .001 & .01 & 0 & 0 & .01 \\
\hline .1 & 1.0 & .001 & .01 & 0 & 0 & 0 & 1.0 & .01 & 0 & 0 & .001 & .01 & .001 & 0 & .001 \\
\hline .1 & 1.0 & .001 & .01 & 0 & 0 & 0 & 1.0 & .01 & .001 & 0 & .001 & .01 & 0 & 0 & .001 \\
\hline 0 & 1.0 & .001 & .01 & 0 & 0 & 0 & 1.0 & .01 & .001 & 0 & .001 & .01 & 0 & 0 & .001 \\
\hline 0 & 1.0 & .001 & .01 & 0 & 0 & 0 & 1.0 & .01 & .001 & 0 & .001 & .01 & .001 & 0 & .001 \\
\hline 0 & 1.0 & .001 & .01 & 0 & 0 & 0 & 1.0 & .01 & .001 & 0 & .001 & .01 & .001 & 0 & .001 \\
\hline .1 & .1 & 0 & .1 & 0 & 0 & 0 & .1 & .01 & .001 & 0 & .001 & .01 & .001 & 0 & .001 \\
\hline 0 & .1 & .01 & 1.0 & .001 & 0 & 0 & 1.0 & .01 & 0 & 0 & .1 & .1 & .001 & 0 & .001 \\
\hline 1.0 & 1.0 & .01 & .1 & 0 & .001 & 0 & 1.0 & .01 & .01 & 0 & .01 & .1 & .001 & 0 & .001 \\
\hline .1 & 1.0 & .01 & .1 & 0 & .001 & 0 & 1.0 & .001 & .001 & 0 & .001 & .1 & .001 & 0 & .001 \\
\hline 0 & 1.0 & .001 & .01 & 0 & .001 & 0 & 1.0 & .01 & 0 & 0 & .001 & .01 & .001 & 0 & .001 \\
\hline
\end{tabular}

\section{ORIGIN}

Smith and Gianella (1942, p. 55) believed that the normal fault (Majuba fault) localized the deposition of the copper ore. The primary sulfide mineral, chalcopyrite, was deposited with arsenopyrite and pyrite along fissures in the faulted rhyolites and as replacements of rhyolite and breccia. The writers agree that the Majuba fault was the largest structure controlling the deposition of the copper deposits. Small faults, such as the two low-angle faults in Myler stope, are believed to have localized smaller ore bodies. The primary sulfides were replaced by secondary copper minerals, especially chalcocite, which enriched the copper-bearing rock to ore grade.

\section{RESTRR VES}

Nearly all the known copper ore bodies have been mined out at the Majuba Hill mine. A small tonnage of relatively low-grade ore is 
believed to be present in the vicinity of the Myler stope, and a very small tonnage of higher grade ore is present in a uraniferous tin- and copper-bearing vein in the Copper stope.

\section{TIN}

The 350 tons of 2 to 4 percent tin ore produced in 1942-45 (Matson, 1948, p. 1) was mined from a tin shoot exposed on the Middle adit level (pl.9). Two composite samples of the tin-bearing rock collected from the Tin stope by the writers contained 0.41 and 0.78 percent tin (pl. 11). This is believed to represent the largest tin deposit in the mine. The uraniferous tin- and copper-bearing vein in the Copper stope contains about 0.47 percent tin; mineralized rhyolite and breccia in stope 211 (pls. 9 and 11) contain from 0.01 to 1.14 percent tin; samples of mineralized rhyolite and breccia collected elsewhere in the mine contained much lower grade tin, from 0.001 to 0.10 percent.

\section{MINERALOGX}

Cassiterite (tin dioxide) is the only tin mineral that has been found at Majuba Hill. It is found in the oxidized zone as well as in the primary sulfide zone and the zone of supergene enrichment of copper. Cassiterite is most conspicuous in the tin shoot exposed in the Tin stope (pl.9), but has also been observed in mineralized breccias and rhyolitic rocks elsewhere in the mine. The cassiterite in the tin shoot is associated with quartz, sericite, iron oxides, tourmaline, and fluorite. Some cassiterite is present in the copper sufide ores in which it is associated with chalcocite, chalcopyrite, pyrite, and arsenopyrite.

Euhedral crystals of dark-brown to yellow-brown cassiterite, less than 0.1 inch wide, are most abundant in tourmaline-bearing breccia in which many of the crystals rest on tourmaline prisms. Some pores left in the earlier rhyolite and rhyolite porphyry by the leaching away of the feldspar phenocrysts are partly filled by cassiterite and tourmaline. Smith and Gianella (1942, p. 49) noted that generally the quartz, tourmaline, sericite, and cassiterite were intimately intergrown, but that locally cassiterite-quartz veinlets cut through tourmaline crystals.

\section{ORIGIN}

Smith and Gianella (1942, p. 47) suggested that the tin and copper deposits were formed either during two separate periods of mineralization or during two distinct phases of a single protracted period of mineralization. They suggested that the cassiterite was formed before the sulfide minerals during a late stage of the quartz-sericite-tourmaline mineralization, and that the cassiterite is slightly younger than the tourmaline. They believed the tin ore shoot to have been displaced 
by the Majuba fault. James Gilluly and L. R. Page (written communication) agreed with Smith and Gianella that the cassiterite was younger than the tourmaline but considered both tin and copper to be of post-Majuba fault age and concluded that no faulted segment of the tin shoot exists.

The present writers agree with Smith and Gianella and with Gilluly and Page that the cassiterite seems to be localized in rubbly, vuggy breccia, especially near the Majuba fault. They also agree with Gilluly and Page that the tin mineralization was post-Majuba fault in age. The general paragenetic sequence of tourmaline, cassiterite, and sulfide minerals was confirmed by the field observations of the writers. However, the tourmaline found coating sulfide minerals and cassiterite along the edges of vugs indicates that the period of its deposition may have overlapped the period of deposition of the sulfide minerals and cassiterite, or that it may have been deposited in periods before and after the cassiterite and sulfide minerals were formed. The tourmaline seems to be related to the breccias and may have been formed in more than one stage since each of the intrusions of breccia was probably followed by its own supply of volatiles.

\section{RESERVES}

Only remnants of the tin ore shoot have been left in the Tin stope (pl. 9). Small reserves of lower grade tin remain in the tin- and copper-bearing vein in the Copper stope and in mineralized rhyolite and breccia in stope 211. Production of tin will depend upon the possible discovery of new deposits. A small amount of exploration on the Middle adit along the Majuba fault to the northwest of the present workings might be justified.

\section{URANIUM}

The only significant uranium deposit at Majuba Hill is contained in a 3-foot copper- and tin-bearing vein in the south part of the Copper stope in the Majuba Hill mine (pls. 9 and 11; coordinate 1700 N, 350$400 \mathrm{~W}$.). The vein is estimated to have an average grade of 0.30 percent $\mathrm{U}_{3} \mathrm{O}_{8}$ and the wall rock, for a width of 15 feet, is estimated to have an average grade of 0.10 percent $\mathrm{U}_{3} \mathrm{O}_{8}$. The vein contains, in addition to the uranium, 0.47 percent tin and 12.7 percent copper. Lower grade uranium-bearing material, containing from 0.004 to 0.04 percent $\mathrm{U}_{3} \mathrm{O}_{8}$, occurs in altered rhyolite porphyry at the extreme south end of drift 202 (pls. 9 and 11). A sample of uraniferous limonitic fault gouge in crosscut 216 contains 0.016 percent $\mathrm{U}_{3} \mathrm{O}_{8}$ (pls. 9 and 11). Most of the other rhyolitic rocks and breccias sampled contained only $0.003-0.006$ percent $\mathrm{U}_{3} \mathrm{O}_{8}$. Radon, the radioactive gaseous daughter product of 
uranium is found in crosscut 215 of the Middle adit level (pls. 9 and 11) and near the end of the Lower adit (pls. 10 and 11) during periods of low barometric pressure. Radon, therefore, suggests the presence of uranium in the vicinity of these workings.

\section{MINGRALOGY}

Metazeunerite is the only uranium-bearing mineral found by the writers at Majuba Hill. It occurs as bright green platy crystals associated with chalcocite, pyrite, arsenopyrite, and cassiterite in the copper- and tin-bearing vein in the Copper stope, and locally with secondary copper minerals, cassiterite, tourmaline, and iron oxides in lower grade rock. No primary mineral of uranium has yet been found.

\section{ORIGIN}

The secondary uranium mineral, metazeunerite, is believed to have been derived from the oxidation of a primary uranium mineral, either uraninite or coffinite, which was deposited with the primary sulfide minerals. The concentration of the metazeunerite with chalcocite suggests that the primary uranium mineral was leached in the oxidized zone and the uranium moved downward to combine with the copper to form the secondary uranium mineral in the zone of supergene enrichment.

\section{RESER VES}

The uranium reserves in the Majuba Hill mine are small, and are limited to the uraniferous copper- and tin-bearing vein in the Copper stope.

\section{SUGGESTIONS FOR PROSPECTING}

Some areas in the Majuba Hill mine are favorable for a small exploratory program for uranium. This exploration could be done either by diamond drilling or by drifting and crosscutting. The following suggestions for prospecting in the mine are presented :

1. The area south of drift 202 in the Middle adit level (pl. 9) appears favorable for finding the downward continuation of the uraniferous vein exposed in the Copper stope.

2. The ground in the vicinity of crosscut 215 (pl. 9) may contain a uranium deposit responsible for the radon in the crosscut.

3. The area near crosscut 216 (pl. 9) may contain a uraniferous deposit, as suggested by the uranium minerals in the 3 -inch gouge in the fault in this crosscut.

4. The area near the end of the Lower adit (pl. 10) might be explored for the source of the radon. 


\section{SUMMARY}

The deposition of the ore minerals of copper, tin, and uranium followed the intrusion of the rhyolitic rocks and breccias and also the major faulting at Majuba Hill. The largest ore bodies have been deposited in the brecciated rocks along the Majuba fault. Only small reserves of copper, tin, and uranium are in sight, and production will depend on the finding of new reserves.

\section{LITERATURE CITED}

Burbank, W. S., 1941, Structural control of ore deposition in the Red Mountain, Sneffels, and Telluride districts, Colorado: Colorado Sci. Soc. Proc., v. 14, p. 141-261.

Gianella, V. P., 1946, Clinoclasite from Majuba Hill, Nev.: Econ. Geology, v. 31, no. 5, p. 259-260.

Matson, E. J., 1948, Investigation of Majuba Hill copper-tin mine, Pershing County, Nev.: U. S. Bur. Mines Rept. of Invest. 4378.

Smith, W. C., and Gianella, V. P., 1942, The tin deposit of Majuba Hill, Pershing County, Nev. : U. S. Geol. Survey Bull. 931-C, p. 39-55.

Vanderburg, W. O., 1936, Reconnaissance of mining districts in Pershing County, Nev.: U. S. Bur. Mines. Inf. Circ. 6902. 


